\title{
Therapeutic Effects of Anthocyanins for Vision and Eye Health
}

\author{
Yuri Nomi ${ }^{1}$, Keiko Iwasaki-Kurashige ${ }^{2}$ and Hitoshi Matsumoto ${ }^{1, *}$ \\ 1 Niigata University of Pharmacy and Applied Life Sciences, 265-1 Higashijima, Akiha-ku, \\ Niigata 956-8603, Japan; ynomi@nupals.ac.jp \\ 2 Functional Material Division, Meiji Food Materia Co., Ltd, 4-16, Kyobashi 2-chome, Chuo-ku, \\ Tokyo 104-0031, Japan; keiko.kurashige@meiji.com \\ * Correspondence: hitoshi.matsumoto@nupals.ac.jp
}

Academic Editors: Takanori Tsuda and Wilhelmina Kalt

Received: 25 August 2019; Accepted: 10 September 2019; Published: 11 September 2019

\begin{abstract}
Anthocyanin (AC) is widely used as supplement of eye health in Europe and in East Asia. In this review, I describe AC effects to clarify the mechanism is important in order to understand the effects of AC on vision health. The bioavailability of AC is quite low but, reported as intact form and many kinds of metabolite. And AC passes through the blood-aqueous fluid barrier and blood-retinal barrier. In vitro study, AC had a relaxing effect on ciliary muscle which is important to treat both myopia and glaucoma. And AC stimulate the regeneration of rhodopsin in frog rod outer segment. Furthermore, AC could inhibit the axial length and ocular length elongation in a negative lens-induced chick myopia model. In addition, we summarized clinical studies of AC intake improved dark adaptation and transient myopic shift and the improvement on retinal blood circulation in normal tension glaucoma patients.
\end{abstract}

Keywords: anthocyanin; myopia; glaucoma; ciliary muscle; blood circulation

\section{Introduction}

During the last decade the rapid growth of smartphone, computer and video display terminal (VDT) use in the office and private place has led to an increase in ocular problems including eye discomfort, blurred vision, eye strain, eye pain and visual fatigue [1,2]. In response to an aging population in developed countries, rates of ocular disease associated with eye strain and external factors such as blue light and UV have increased.

An anthocyanin (AC) complex from bilberry (Vaccinium myrtillus L.) fruit is widely used in Europe for medicinal purposes [3] and as a dietary supplement in countries in East Asia, especially Japan [4]. Bilberry AC has been reported to enhance night visual acuity [5] and is used as a supplement to improve vision health [3].

Consumers have access to a wide range of methods and treatments to mitigate the effects ophthalmologic disorders. However, whether AC consumption can improve ophthalmologic health is unclear. Ophthalmologic diseases often have a variety of symptoms, and a single supplement such as AC is unlikely to produce improvement in all ophthalmologic disorders. Thus, clarification of the mechanisms by which AC could improve vision health and provide beneficial effects to lessen the symptoms of ophthalmologic disorders such as asthenopia, myopia and glaucoma is needed. Canter and Ernst reviewed clinical studies that focused on the use of bilberry AC supplementation to improve night vision by, but the results for these studies were negative [6]. Kalt et al. also reviewed studies that focused on the polyphenol's effects on vision health [7] including in vitro researches demonstrating that ACs and other flavonoids interact with rhodopsin to modulate visual transductional function, although 
the relationship between the mechanism of action and clinical benefits of these agents remains unclear. Accordingly, we began to evaluate the physiological effects of AC in the context of vision health.

There are multiple types of $\mathrm{AC}$ high content fruits and vegetables, wherein varieties of $\mathrm{AC}$ differ depending on the food's origin. In our research we focused on AC from blackcurrant fruits (Ribes nigrum L.), which are rich in AC and are commonly consumed worldwide. With only four different $\mathrm{AC}$, the $\mathrm{AC}$ composition of blackcurrants is simpler than that for bilberries, which have fifteen AC components (Figure 1). The typical profile of blackcurrant anthocyanin (BCA) is $47 \%$ delphinidin-3-rutinoside (D3R), 13\% delphinidin-3-glucoside (D3G), 35\% cyanidin-3-rutinoside (C3R) and $5 \%$ cyanidin-3-glucoside (C3G). These four ACs have been purified and crystallized [8].<smiles>[Y]Oc1cc2c(O)cc(O)cc2[o+]c1-c1cc([X])c(O)c(O)c1</smiles>

Figure 1. Structure of anthocyanin in blackcurrants. The chemical structure of each of the four anthocyanins (ACs) is as follows: D3R ( $\mathrm{X}=\mathrm{OH}, \mathrm{Y}=$ glucosylrhamnose), $\mathrm{D} 3 \mathrm{G}(\mathrm{X}=\mathrm{OH}, \mathrm{Y}=$ glucose), C3R $(X=H, Y=$ glucosylrhamnose $)$ and C3G $(X=H, Y=$ glucose $)$.

This review covers the published and unpublished work concerning the effect of AC on vision health from our and other groups. We reported that D3R has a relaxing effect after Endothelin-1 induced contraction on bovine ciliary muscle [9]. One theory for the cause of refractive myopia in childhood is that ciliary muscle becomes spastic as hyper-contraction during close up work (near work), leading to spasmodic refraction of the lens [10]. Extensive studies have been conducted to identify agents that can promote ciliary muscle $(\mathrm{CM})$ relaxation and would be valuable to treat both glaucoma and pseudo myopia [11]. We also reported that cyanidin glycosides stimulate the regeneration of rhodopsin in frog rod outer segment membranes in vitro [12]. In another study we showed that AC treatment decreases axial and ocular length elongation in chicks fitted with negative lens that serves as an animal model of myopia $[13,14]$. In a series of investigations in a double-masked, placebo-controlled, crossover study on humans we demonstrated that the ingestion of BCA improved dark adaptation and transient myopic shift of refractive status [15]. Meanwhile, Ohguro et al. showed that AC affects the blood flow in retina in normal tension glaucoma patients [16,17].

\section{BCA Properties, Bioavailability and Distribution in Eye Tissues}

There are many reports suggest that $\mathrm{AC}$ are absorbed directly (without any metabolization) and then distributed in the blood before being excreted intact into the urine [18-20]. BCA consists mainly of AC rutinosides, which have higher bioavailability compared to AC monoglucoside precursors. Indeed, after a $200 \mathrm{mg}$ oral dose of $\mathrm{BCA}$, the total recovery rate of the $\mathrm{AC}$ rutinoside in the urine is around $0.1 \%$ whereas that of the $\mathrm{AC}$ glucoside is only $0.05 \%$. In total, the concentration of $\mathrm{BCA}$ components in human plasma reached $35 \mathrm{nmol} / \mathrm{L}$ [21]. However, AC degradation products and metabolites are also reported in humans and rats including phenolic acids derivatives (e.g., gallic acid, protocatechuic acid, syringic acid, vanillic acid, caffeic acid, phloroglucinol acid and phloroglucinol aldehyde [22,23].

Furthermore, Czank et al. conducted a study using ${ }^{13} \mathrm{C}$-labeled C3G to examine human metabolism of AC [24]. In this study, eight adult male volunteers received $500 \mathrm{mg}{ }^{13} \mathrm{C}$-labeled C3G and ${ }^{13} \mathrm{C}$ levels in blood, urine, feces and breath were measured over the next $48 \mathrm{~h}$. The calculated bioavailability was $12.38 \% \pm 1.38 \%$. They found that ${ }^{13} \mathrm{C}$ is excreted both as intact $\mathrm{C} 3 \mathrm{G}$, as well as various conjugates and metabolites such as cyanidin glucuronate conjugate, cyanidin sulfate conjugate, protocatechuic acid, 
4-dihydroxyphenylacetic acid, vanillic acid, 4-hydroxyphenylacetic acid, ferulic acid caffeic acid and hippuric acid; the main $\mathrm{AC}$ metabolites are hippuric acid and carbon dioxide.

The action of these AC decomposition products and metabolites should be considered in the context of mechanistic effects, particularly since these substances are produced not only from ACs, but also from other polyphenols. We hypothesize that these products including intact AC, represent the physiologically active agents of $\mathrm{AC}$, despite their low level of uptake.

BCA passes intact through the blood-brain barrier and blood-retinal barrier in both rabbits and rats after intravenous and intraperitoneal administration, respectively [25]. In addition, the total concentration of AC in several ocular tissues was higher than that measured in plasma, a finding that suggests that $\mathrm{AC}$ can concentrate in ocular tissues. We also found significantly high AC concentrations in some ocular tissues when BCA was administered either intravenously or intraperitoneally (Table 1). In rats given intraperitoneal administration of $108 \mathrm{mg} \mathrm{AC} /$ body weight $(\mathrm{BW}) \mathrm{kg}$, we showed that intact AC is absorbed and distributed into ocular tissues including the cornea $(20.6 \mu \mathrm{g} / \mathrm{g})$, aqueous humor $(6.72 \mu \mathrm{g} / \mathrm{mL})$, ciliary body and iris $(12.9 \mu \mathrm{g} / \mathrm{g})$, sclera with choroid $(245 \mu \mathrm{g} / \mathrm{g})$ and retina $(6.89 \mu \mathrm{g} / \mathrm{g})$ with a plasma concentration of $2.30 \mu \mathrm{g} / \mathrm{mL}$. The high AC concentration in the choroid may be due to the propensity of AC to bind proline-rich proteins such as collagen, which is abundant in this tissue [26]. In rabbits, $30 \mathrm{~min}$ after intravenous administration of $4.32 \mathrm{mg} / \mathrm{BW} \mathrm{kg}$ AC were undetectable in the lens, but present in the sclera $(3.0 \mu \mathrm{g} / \mathrm{g})$, choroid $(3.0 \mu \mathrm{g} / \mathrm{g})$, cornea $(0.55 \mu \mathrm{g} / \mathrm{g})$, aqueous humor $(1.19 \mu \mathrm{g} / \mathrm{mL})$, ciliary body $(2.04 \mu \mathrm{g} / \mathrm{g})$, iris $(1.11 \mu \mathrm{g} / \mathrm{g})$ and retina $(6.89 \mu \mathrm{g} / \mathrm{g})$, whereas the plasma concentration was $12.42 \mu \mathrm{g} / \mathrm{mL}$. The eye tissue distribution of orally administered AC could not be determined due to the low concentrations in both the plasma and whole eyeball (approximately $1 \mu \mathrm{g} / \mathrm{mL}$ and $100 \mathrm{ng} / \mathrm{g}$, respectively). In conclusion, the results show that ACs can pass the blood-retinal barrier after oral administration, but uptake is more effective with intraperitoneal or intravenous delivery.

Table 1. The ocular tissue distribution of AC at $1 \mathrm{~h}$ post-intraperitoneal administration in rats and at 30 min post-intravenous administration in rabbits. Mean $\pm \mathrm{SE}, n=5$ in rats, and $n=3$ in rabbits.

\begin{tabular}{ccccc}
\hline $\begin{array}{c}\text { Ocular Tissues or } \\
\text { Body Fluid }\end{array}$ & \multicolumn{2}{c}{ Intraperitoneal Administration in Rat } & \multicolumn{2}{c}{ Intravenously Administration in Rabb } \\
\cline { 2 - 5 } & $\begin{array}{c}\text { AC of Tissue }(\mu \mathrm{g} / \mathrm{g} \\
\text { Tissue) }\end{array}$ & $\begin{array}{c}\text { Distribution Ratio } \\
\mathbf{( \% )}\end{array}$ & $\begin{array}{c}\text { AC of Tissue }(\mu \mathrm{g} / \mathrm{g} \\
\text { Tissue) }\end{array}$ & $\begin{array}{c}\text { Distribution Ratio } \\
\mathbf{( \% )}\end{array}$ \\
\hline Aqueous humor & 6.72 & 0.88 & $1.19 \pm 0.21$ & 10.54 \\
Cornea & 20.62 & 3.67 & $0.55 \pm 0.05$ & 4.89 \\
Sclera & 245.04 & 89.09 & $3.02 \pm 0.09$ & 26.73 \\
Choroid & & & $3.00 \pm 0.06$ & 26.57 \\
Ciliary body & 12.93 & 1.39 & $2.04 \pm 0.28$ & 18.07 \\
Iris & 6.89 & 4.76 & $1.11 \pm 0.08$ & 9.81 \\
Retina & 0.60 & 0.14 & $0.27 \pm 0.02$ & 2.41 \\
Vitreous & 0.36 & 0.06 & $0.11 \pm 0.02$ & 0.98 \\
Lens & $2.30 \pm 0.76$ & & $0.00 \pm 0.00$ & 0.00 \\
Plasma * & & & $12.42 \pm 1.25$ & \\
\hline
\end{tabular}

$*$ : $\mu \mathrm{g} / \mathrm{mL}$.

\section{Stimulatory on Rhodopsin Regeneration by Cyanidin Glycosides}

In the retinal rod outer segment (ROS), G-protein-coupled receptor rhodopsin localizes on lipid bilayers on laminated discs. Following light absorption, 11-cis-retinal isomerizes to all-trans-retinal in rhodopsin chromophore. Rhodopsin subsequently changes to further conformation through some intermediates chromophore and triggers some reactions through phototransduction cascade [27]. Metarhodopsin II is one of intermediate in this cascade, which activates more than 500 transducin molecules per seconds to amplify photo signals [28,29]. Thereafter, transducin activates cGMP phosphodiesterase to hydrolyze cGMP that results in closure of cation channels and subsequent cell hyperpolarization. All components of the phototransduction pathway recover their original inactive state after light activation. Light-activated rhodopsin is inactivated by phosphorylation and is then 
dephosphorylated before returning to a state to opsin, which is the protein moiety of rhodopsin (Figure 2). Rhodopsin is regenerated upon binding of the opsin protein and 11-cis-retinal. ACs are proposed to affect rhodopsin regeneration [30] and bilberry extract has also been shown to stimulate rhodopsin regeneration [31].

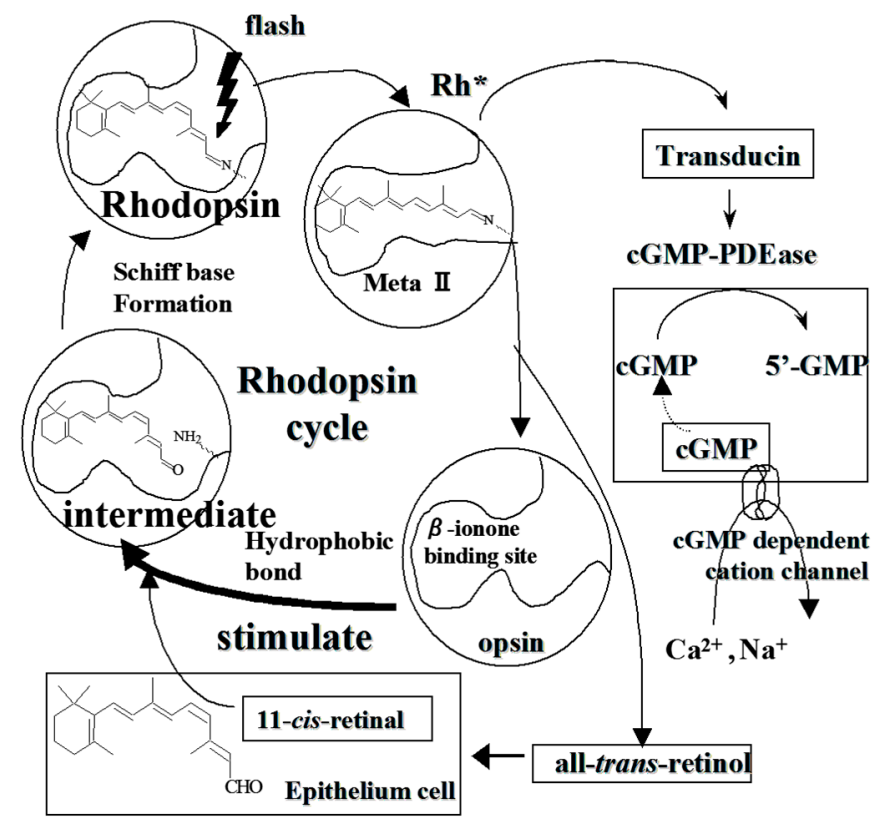

Figure 2. Schematic diagram of rhodopsin regeneration by anthocyanin.

We examined the effect of $\mathrm{AC}$ on rhodopsin regeneration using the four different ACs found in blackcurrants and purified 11-cis-retinal [12]. Rhodopsin regeneration was measured by $10 \mathrm{~min}$ reaction after 11-cis-retinal addition, with or without one of four ACs $(0.1 \mathrm{mM})$ to compile a time course of rhodopsin regeneration. The kinetics of rhodopsin regeneration can be expressed by the below mentioned equation:

$$
\text { 11-cis-retinal }+ \text { opsin } \underset{k-1}{\stackrel{k 1}{\rightleftarrows}} \text { INT } \stackrel{k 2}{\longrightarrow} \text { rhodopsin. }
$$

INT is a regeneration intermediate and $\mathrm{k}_{1}, \mathrm{k}_{-1}$ and $\mathrm{k}_{2}$ are rate constants.

The velocity of equation 1 reaction with saturating 11-cis-retinal is:

$$
\mathrm{v}_{\mathrm{obsd}}=\mathrm{k}_{2} \times[\mathrm{opsin}] \times[11 \text {-cis-retinal }] /\left(\mathrm{K}_{\mathrm{m}}+[11 \text {-cis-retinal }]\right),
$$

where $\mathrm{v}_{\mathrm{obsd}}$ is the observed rate of rhodopsin regeneration at the actual concentration of 11-cis-retinal and $\mathrm{K}_{\mathrm{m}}=\left(\mathrm{k}_{-1}+\mathrm{k}_{2}\right) / \mathrm{k}_{1}$.

$\mathrm{K}_{\mathrm{m}}$ is a kinetic parameter that describes the regeneration of rhodopsin. D3R and D3G had no effect on regeneration of rhodopsin, whereas C3R and C3G had stimulation of regeneration (Figure 3). This result demonstrates that cyanidin mono- and diglycosides, but not D3G or D3R, accelerate rhodopsin regeneration in vitro. 


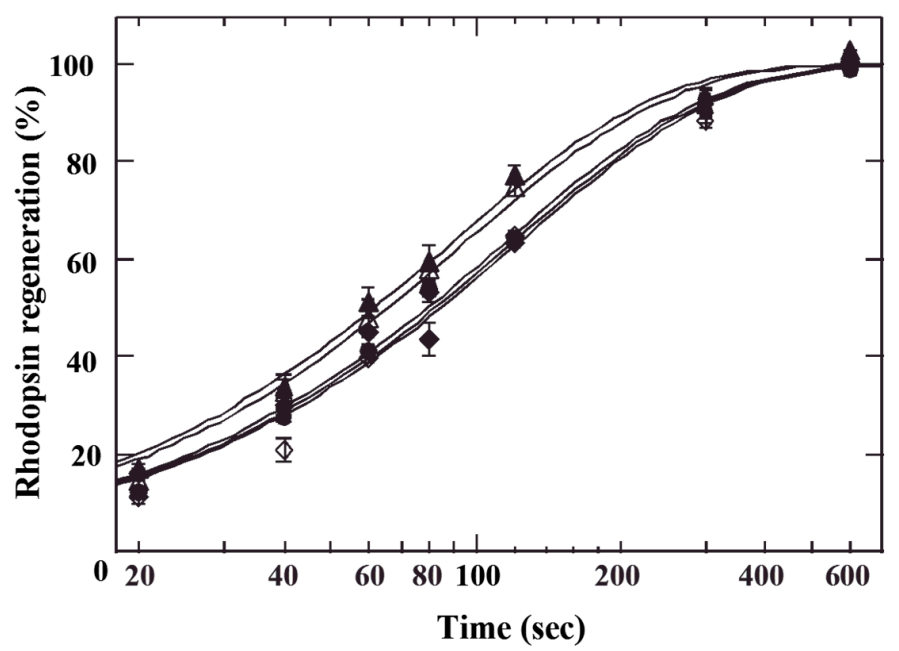

Figure 3. AC effects of the rhodopsin regeneration time course. (•) control; $(\diamond)$ D3G; $(\diamond)$ D3R; $(\triangle)$ C3G; ( $\mathbf{\Delta})$ C3R. Rhodopsin regeneration was fitted to an exponential function of 1-exp $(-t / \tau)$. Control, $\tau=114 \mathrm{sec}\left(R^{2}=0.997\right) ; D 3 G, \tau=122 \mathrm{sec}\left(R^{2}=0.988\right) ; D 3 R, \tau=119 \sec \left(R^{2}=0.993\right) ; C 3 G, \tau=94 \sec$ $\left(R^{2}=0.994\right)$ and C3R, $\tau=89 \mathrm{sec}\left(R^{2}=0.994\right)$. Values are the mean of nine experiments, and vertical bars represent SEM.

Equation (2) given above represents the observed rate of regeneration that is dependent upon [11-cis-retinal], $\mathrm{k}_{1}, \mathrm{k}_{-1}$ and $\mathrm{k}_{2}$. To estimate these rate constants, the initial rhodopsin regeneration speed was measured by $\mathrm{v}_{\text {obsd }}$ as a function of [11-cis-retinal]. The initial velocity of regeneration was measured for $40 \mathrm{~s}$ with C3R, the major cyanidin diglycoside (34.7\%) in blackcurrants, at various 11-cis-retinal concentrations and the results were fitted to equation (2) to obtain $k_{2}$ and $K_{m}$ with or without C3R (open and closed symbols, respectively; Figure 4). C3R did not affect $k_{2}$, but did decrease the $\mathrm{K}_{\mathrm{m}}$ value by 2.4-fold compared to controls (Table 2). This decrease in $\mathrm{K}_{\mathrm{m}}$ could be caused by either $\mathrm{k}_{1}$ increase or $\mathrm{k}_{-1}$ decrease, although we could not determine which change caused a $\mathrm{K}_{\mathrm{m}}$ decrease. However, the results do indicate that production of a regeneration intermediate is accelerated by C3R.

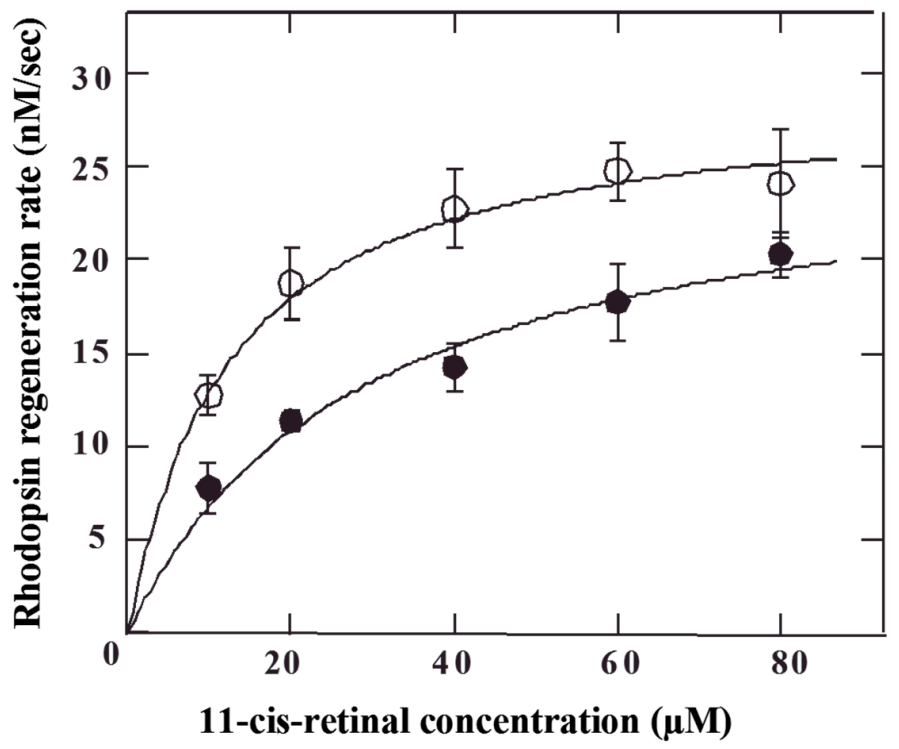

Figure 4. Effect of C3R on the initial rate of rhodopsin regeneration. Initial velocity of rhodopsin regeneration was determined for $40 \mathrm{~s}$ in the $\mathrm{C} 3 \mathrm{R}(\bigcirc)$ and control $(\bullet)$ at each 11-cis-retinal concentration. The data points were fitted with eq 2 to calculate rate constants in the regeneration reaction $(n=6$, mean $\pm S E)$. 
Table 2. Kinetic parameters of rhodopsin regeneration.

\begin{tabular}{ccc}
\hline & Control $^{*}$ & +C3R $^{*}$ \\
\hline $\mathrm{k}_{2}\left(\mathrm{~s}^{-1}\right)$ & $1.0 \times 10^{-2}$ & $1.1 \times 10^{-2}$ \\
$\mathrm{~km}(\mathrm{M})$ & $2.6 \times 10^{-5}$ & $1.1 \times 10^{-5}$ \\
\hline \multicolumn{2}{c}{${ }^{*} \mathrm{R}^{2}=0.989$ (control); 0.995 (+C3R). }
\end{tabular}

Fain et al reported that, after photobleaching, opsin can still be active in the phototransduction cascade to reduce intracellular $\mathrm{Ca}^{2+}$ concentrations to decrease light-sensitivity of rod cells [32]. Acceleration of rhodopsin regeneration by $\mathrm{AC}$ might therefore promote the corresponding acceleration of rod cell light-sensitivity.

\section{Key Effect of Anthocyanin in Ophthalmologic Field}

\subsection{Ciliary Muscle Relaxation Induced by Anthocyanins}

Ciliary muscle (CM) controls lens focus, production of aqueous humor and participates in maintaining ocular pressure. $\mathrm{CM}$ thus has been the focus of multiple studies as a potential target for anti-glaucoma [33], myopia [34] and visual fatigue therapies [11]. To define AC recovery in transient refraction change, we examined the effect of $\mathrm{AC}$ on endothelin (ET)-1-induced contraction of CM to determine whether smooth muscle relaxation pathways are affected by these AC [9].

$\mathrm{CM}$ from a bovine eye was extirpated and measured of muscle tension according to a previous method [35]. After reaching stable isometric tension, CM was pre-contracted at twenty minute intervals using physiological saline solution (PSS) containing $65 \mathrm{mM} \mathrm{KCl}$. After washing with PSS and allowing the CM to return to baseline, ET-1 was treated to stimulate muscle contraction by pharmacological concentration of $10 \mathrm{nM}$ [35] and the change of isometric tension was measured using a force-displacement transducer. When the isometric tension had stabilized, a $30 \mu \mathrm{M} \mathrm{C3R}$, D3R, myricetin-3-rutinoside (M3R) or quercetin-3-rutinoside (Q3R) was dropped in a single aliquot. Vehicle (distilled water) was added for the control. The relaxation within $60 \mathrm{~min}$ of the addition was measured to determine the relative tension (Figure 5).

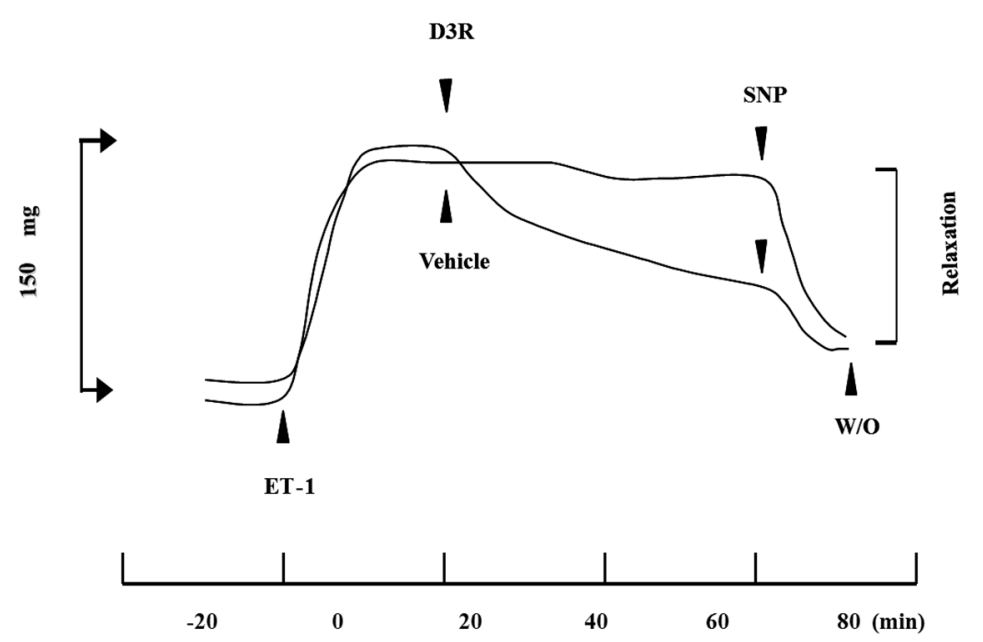

Figure 5. Ciliary muscle relaxation by D3R against ET-1induced contraction. $10 \mathrm{nM}$ ET-1 produced a phasic contraction, followed by a tonic contraction. When the tonic contraction reached a steady level, $30 \mu \mathrm{M}$ D3R or $\mathrm{H}_{2} \mathrm{O}$ (vehicle) was added and the resulting relaxation was monitored for $60 \mathrm{~min}$. SNP (sodium nitroprusside) is a positive control of relaxation as an NO donor. W/O is a washout of all reagents and solution. 
The values for relative tension with D3R and C3R treatment had a significant difference with the control that occurred without the addition of any compound (Figure 6). Treatment with BCA (50 mg/mL) also had significant relaxation activity. Whereas Q3R and M3R, which had a similar structure with C3R and D3R, showed no relaxation activity within a 60 min treatment (Figure 6).

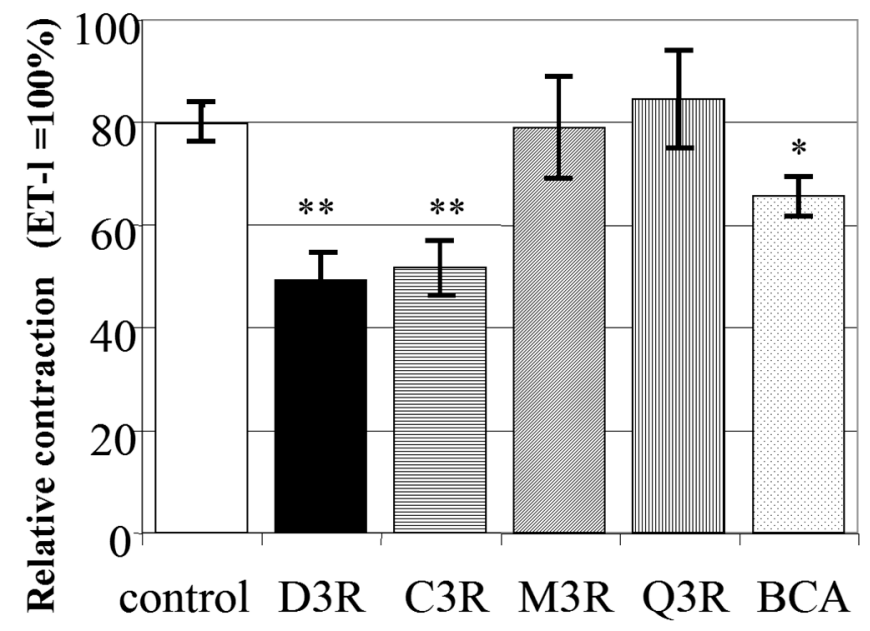

Figure 6. Summary of data obtained from relaxation during a 60 minute treatment of four flavonoids compared to the control. ${ }^{*} p<0.05,{ }^{* *} p<0.01$; significantly different compared to the control. The data represent the force generated with ET-1 $(10 \mathrm{nM})$ set to $100 \% . n=6$, mean \pm SEM.

\subsection{D3R Has an Inhibitory Effect against CM Contraction}

CM contraction is mediated by several receptors [35,36], whereas relaxation is administrated by two mechanisms, one cAMP-dependent pathway that includes beta-adrenergic and prostaglandin receptor participated responses, and the other CAMP-independent that involves an NO involving relaxation [37]. It was reported that relaxation of bovine $\mathrm{CM}$ was regulated by $\mathrm{NO}$ similar with that of vascular smooth muscle [35]. These non-autonomic mechanisms of CM relaxation have been studied and developed both myopia and glaucoma drags [11]. Thieme reported that after unoprostone treatment a relaxation specific to ET-1 induced-contraction can be observed that is similar to that seen for pre-treatment with D3R [33]. Using this pre-treatment effect, we tried to determine whether signal transduction pathways in CM were effective using D3R pretreatment by examining contraction ratios developed as decreased \% of maximum contraction (Table 3). The $0.1 \mathrm{mM}$ D3R pretreatment significantly reduced contraction induced by $10 \mathrm{nM}$ ET-1 from $54.9 \% \pm 15.0 \%$ to $42.2 \% \pm 3.2 \%$. The influence of several inhibitors was then examined to study the mechanism of CM relaxation [33,34,38]. The beta-adrenergic blocker propranolol $(0.1 \mathrm{mM})$, the $\mathrm{K}^{+}$channel blocker iberiotoxin $(0.1 \mu \mathrm{M})$ or the cyclooxygenase inhibitor indomethacin $(0.1 \mathrm{mM})$ were added $20 \mathrm{~min}$ before the addition of D3R produced no significant change in the D3R effect on contraction induced by treatment with ET-1 (10 nM), suggesting that these pathways that are beta-adrenergic or maxi-K $\mathrm{K}^{+}$channels or the $\mathrm{PGI}_{2}$ pathway did not involve relaxation by D3R (Table 3).

Meanwhile, pretreatment for $20 \mathrm{~min}$ with $0.1 \mathrm{mM} \mathrm{NOARG} \mathrm{(L-NG}$-nitro arginine), the NOS inhibitor, increased the contraction ratio and reversed the D3R inhibitory effect (Table 3). The D3R contraction ratio was increased by NOARG addition and was decreased by the addition of NOARG with L-arginine. These findings imply that D3R could stimulate NO release and promote CM relaxation. Treatment with the guanylyl cyclase (GC) inhibitor ODQ $\left({ }^{1} \mathrm{H}-[1,2,4]\right.$ oxadiazolo [4,3-a] quinoxalin-1-one) $20 \mathrm{~min}$ before D3R addition increased the contraction, but ODQ alone had no effect on CM contraction. In other experiments, NO scavenger carboxy-PTIO $(0.3 \mathrm{mM}) 20 \mathrm{~min}$ before D3R addition increased the contraction, but carboxy-PTIO alone had a similar effect. These results suggested that D3R effect was likely caused by enhanced NO synthesis in the endothelium cells through guanylyl cyclase activation. Addition of BQ788 $(0.1 \mu \mathrm{M})$, a selective $\mathrm{ET}_{\mathrm{B}}$ receptor antagonist, augmented the contraction ratio, 
as did BQ788 alone. It was confirmed that D3R enhances NO synthesis that stimulates $\mathrm{ET}_{\mathrm{B}}$ receptor activity in the CM.

Table 3. Comparison of contraction of the ciliary muscle by ET-1 (10 nM) after treatment with various reagents.

\begin{tabular}{|c|c|c|c|}
\hline Treatment & Concentration & $n$ & Contraction $(\%)($ Average $\pm S E)$ \\
\hline control & & 21 & $54.9 \pm 3.3^{a}$ \\
\hline D3R & $10 \mathrm{mM}$ & 21 & $42.2 \pm 3.2$ \\
\hline $\mathrm{D} 3 \mathrm{R}+\mathrm{NOARG}$ & $10 \mathrm{mM}+10 \mathrm{mM}$ & 12 & $63.7 \pm 7.1^{\mathrm{a}}$ \\
\hline $\mathrm{D} 3 \mathrm{R}+\mathrm{NOARG}+\mathrm{L}-\mathrm{Arg}$ & $10 \mathrm{mM}+10 \mathrm{mM}+10 \mathrm{mM}$ & 12 & $42.7 \pm 4.2$ \\
\hline Carboxy-PTIO & $30 \mathrm{mM}$ & 10 & $54.4 \pm 2.1$ \\
\hline D3R + Carboxy-PTIO & $10 \mathrm{mM}+30 \mathrm{mM}$ & 10 & $55.2 \pm 3.2^{\mathrm{a}}$ \\
\hline ODQ & $10 \mathrm{mM}$ & 11 & $56.1 \pm 5.4$ \\
\hline $\mathrm{D} 3 \mathrm{R}+\mathrm{ODQ}$ & $10 \mathrm{mM}+10 \mathrm{mM}$ & 11 & $58.5 \pm 5.5^{a}$ \\
\hline BQ788 & $10 \mu \mathrm{M}$ & 12 & $81.0 \pm 8.2$ \\
\hline $\mathrm{D} 3 \mathrm{R}+\mathrm{BQ} 788$ & $10 \mathrm{mM}+10 \mu \mathrm{M}$ & 12 & $73.4 \pm 9.6^{\mathrm{a}}$ \\
\hline propranolol & $10 \mathrm{mM}$ & 9 & $61.3 \pm 3.6$ \\
\hline $\mathrm{D} 3 \mathrm{R}+$ propranolol & $10 \mathrm{mM}+10 \mathrm{mM}$ & 8 & $48.7 \pm 3.4^{b}$ \\
\hline iberiotoxin & $10 \mu \mathrm{M}$ & 12 & $64.6 \pm 3.0$ \\
\hline $\mathrm{D} 3 \mathrm{R}+$ iberiotoxin & $10 \mathrm{mM}+10 \mu \mathrm{M}$ & 12 & $45.7 \pm 4.8^{\mathrm{c}}$ \\
\hline indomethacin & $10 \mathrm{mM}$ & 12 & $70.3 \pm 5.3$ \\
\hline D3R + indomethacin & $10 \mathrm{mM}+10 \mathrm{mM}$ & 12 & $52.4 \pm 5.2^{d}$ \\
\hline
\end{tabular}

a Significant difference at $p<0.05$ vs. D3R treatment; ${ }^{\mathrm{b}}$ Significant difference at $p<0.05 \mathrm{vs}$. propranolol treatment; ${ }^{\mathrm{c}}$ Significant difference at $p<0.05$ vs. iberiotoxin treatment; ${ }^{\mathrm{d}}$ Significant difference at $p<0.05$ vs. indomethacin treatment.

\subsection{Myosin Regulatory Light Chain (RLC) Phosphorylation and Cyclic}

GMP production in ciliary muscle contraction of $\mathrm{CM}$ is activated and increased cytosolic free $\mathrm{Ca}^{2+}$ concentration, which saturates four $\mathrm{Ca}^{2+}$-binding sites of calmodulin molecules [39]. Saturated calmodulin $\left(\left(\mathrm{Ca}^{2+}\right) 4\right.$-calmodulin) activates myosin light chain kinase (MLCK) that catalyzes phosphorylation of Ser19 in motor protein myosin II at two of its 20-kDa MLC subunits (LC20) [40]. These phosphorylated reaction increases the actin-activated Mg-ATPase activity in myosin, which provides the energy of the development of force and muscle contraction [41]. MLCK can also phosphorylate LC20 at Thr18 in vitro, but only at very high (i.e., non-physiological) concentrations of the kinase [42,43]. Upon removal of $\mathrm{Ca}^{2+}$ from the cytosol, the CM relaxes and MLCK is deactivated whereupon myosin is dephosphorylated by MLC phosphatase, a type 1 Ser/Thr type [44].

To further examine the D3R effect against CM contraction (Table 3), we measured MLC phosphorylation in bovine $\mathrm{CM}$ during tension of contraction by $\mathrm{D} 3 \mathrm{R}$ pretreatment following the addition of ET-1 $(10 \mathrm{nM})$ and other agents. After treatment, the CM were quickly frozen in liquid $\mathrm{N}_{2}$ and then weighed before placement in a frozen slurry of $10 \%$ wt/v trichloroacetic acid in acetone containing $10 \mathrm{mM}$ 1,4-dithiothreitol. We measured phosphorylated and non-phosphorylated ratio of myosin in order to evaluate phosphorylation ratio [45], and found that the ratio decreased significantly. Pretreatment with NOARG or excess L-arginine increased and decreased the ratio, respectively (Table 4).

Levels of cGMP were measured in quick-frozen CM that was treated as described above. After 10 min incubation to thaw the solution, the liquid was removed and the CM was homogenized in 60 volumes of TCA-acetone-DTT solution. Following centrifugation of the homogenate at $3000 \mathrm{~g}$ for $3 \mathrm{~min}$, the supernatant and precipitate were removed for measurement of cGMP and myosin MLC phosphorylation concentration, respectively. The supernatant was five times extracted with four volumes of water-saturated diethyl ether to remove TCA after evaporated in a centrifugal vaporizer. The dried extract was pretreated with $10 \mu \mathrm{M}$ 3-isobutyl-1-methylxanthine to inhibit degradation of cyclic GMP. The cGMP content was quantified using a radioimmunoassay kit [45]. Basal cGMP levels were $13.4 \pm 0.6 \mathrm{pmol} / \mathrm{mg}$ tissue. ET-1 decreased these levels to $6.58 \pm 0.78 \mathrm{pmol} / \mathrm{mg}$ tissue. The addition of IBMX significantly decreased ET-1 contraction $(54.9 \% \pm 3.3 \%)$, whereas the decrease mediated by 
D3R was $42.2 \% \pm 3.2 \%$ where the cGMP concentration $(9.39 \pm 0.96 \mathrm{pmol} / \mathrm{mg}$ tissue $)$ was increased. These changes were inhibited by the addition of $0.1 \mathrm{mM}$ NOARG $(5.09 \pm 0.37 \mathrm{pmol} / \mathrm{mg}$ tissue).

Table 4. Comparison between ET-1 induced ciliary muscle contraction ratio and phosphorylated MLC ratio.

\begin{tabular}{cccc}
\hline Treatment & Concentration & $\begin{array}{c}\text { Contraction (\%) } \\
\text { (Average } \pm \text { SE) }\end{array}$ & $\begin{array}{c}\text { Phosphorylated-Ratio } \\
\text { (\%) (Average } \pm \text { SE) }\end{array}$ \\
\hline control & & $54.9 \pm 3.3^{\mathrm{a}}$ & $47.2 \pm 13.1^{\mathrm{a}}$ \\
D3R & $10 \mathrm{mM}$ & $42.2 \pm 3.2^{\mathrm{a}}$ & $36.0 \pm 13.6$ \\
D3R + NOARG & $10 \mathrm{mM}+10 \mathrm{mM}$ & $63.7 \pm 7.1^{\mathrm{a}}$ & $50.1 \pm 4.2^{\mathrm{a}}$ \\
D3R + NOARG + L-Arg & $10 \mathrm{mM}+10 \mathrm{mM}+10 \mathrm{mM}$ & $42.7 \pm 4.2^{\mathrm{b}}$ & $38.2^{\mathrm{b}} \pm 7^{\mathrm{c}}$ \\
\hline
\end{tabular}

\footnotetext{
${ }^{\text {a }}$ Significant difference at $p<0.05$ vs. D3R treatment; ${ }^{b}$ Significant difference at $p<0.05$ vs. D3R + NOARG;

c Significant difference at $p<0.01$ vs. D3R + NOARG.
}

Nathanson and McKnee demonstrated that normal human CM has highly endothelial cell NO synthase [46] and NO mediates smooth muscle relaxation by increasing cGMP production [47]. Sodium nitroprusside is a direct reagent of the NO donor, and provides rapid relaxation of smooth muscle following carbamoylcholine chloride (cholinergic agonist) or ET-1 induced contraction [48]. Furthermore, the NO synthase substrate L-canavanine has similar relaxing properties in bovine ciliary smooth muscle, particularly against ET-1 contraction compared to contraction by cholinergic agonist [11]. Thus, we hypothesized that D3R affects NO production or release that in turn leads to relaxation of ciliary smooth muscle.

\subsection{Endothelin Receptor Binding Assay in Ciliary Muscle}

To determine the ET receptor localization at which D3R mediates its effects on CM, a receptor binding assay was performed in CM and ciliary epithelium cells (CE) using [ $\left.{ }^{125} \mathrm{I}\right]$ ET-1 for saturation analysis. Specific ET binding was calculated as total binding minus non-specific binding using $125 \mathrm{nmol} / \mathrm{L}$ unlabeled ET-1. Specific binding of [ $\left.{ }^{125} \mathrm{I}\right] \mathrm{ET}-1$ (50 pmol/L) was replaced by the selective $\mathrm{ET}_{\mathrm{A}}$ receptor antagonist $\mathrm{BQ123}(0.1 \mathrm{nM}$ to $7.81 \mu \mathrm{M})$ and the selective $\mathrm{ET}_{\mathrm{B}}$ receptor antagonist $\mathrm{BQ788}$ $(0.1 \mathrm{nM}$ to $7.81 \mu \mathrm{M})[9]$. The $\left[{ }^{125} \mathrm{I}\right]-\mathrm{ET}-1$ binding was highly affinity in CM. Scatchard plot analysis clarified that the $\left[{ }^{125} \mathrm{I}\right]-\mathrm{ET}-1$ binding sites constituted a single population because Hill coefficients were close to unity ( $\mathrm{nH}=0.99 \pm 0.02$ and $1.04 \pm 0.04$ in $\mathrm{CE}$ and $\mathrm{CM}$, respectively). In the CE the dissociation equilibrium constant $\left(\mathrm{K}_{\mathrm{d}}\right)$ and receptor density $\left(\mathrm{B}_{\max }\right)$ values were determined equal to $54.5 \pm 4.6 \mathrm{nM}(n=4)$ and $168.4 \pm 25.4 \mathrm{fmol} / \mathrm{mg}$ protein $(n=4)$, respectively. In the $\mathrm{CM}, \mathrm{K}_{\mathrm{d}}$ and $\mathrm{B}_{\max }$ values were found $141.7 \pm 18.0 \mathrm{nM}(n=4)$ and $357.7 \pm 35.8 \mathrm{fmol} / \mathrm{mg}$ protein $(n=4)$, respectively. In the presence of BQ123, the specific $\left[{ }^{125} \mathrm{I}\right]-\mathrm{ET}-1$ binding in $\mathrm{CM}$ or CE was partially inhibited (by $\sim 40 \%$ ). However, binding was inhibited by BQ788, completely. The $\mathrm{K}_{\mathrm{i}}$ values for BQ788 were calculated equal to $56.7 \pm 10.8 \mathrm{pM}$ in $\mathrm{CE}$ and $93.4 \pm 23.3 \mathrm{pM}$ in $\mathrm{CM}$. Although the $\mathrm{ET}_{\mathrm{B}}$ receptor sub-type predominates in both $\mathrm{CE}$ and $\mathrm{CM}$, the binding kinetics differed.

\subsection{Summary of Anthocyanin Effect for Ciliary Smooth Muscle Relaxation}

D3R pretreatment had a preventive effect against ET-1 contraction in CM (Table 3) with a simultaneous increase in cGMP production and decrease with MLC phosphorylation. In the presence of NOARG as the NOS inhibitor, carboxy-PTIO as the NO scavenger, ODQ as the inhibitor of guanylyl cyclase or BQ788 as the $\mathrm{ET}_{\mathrm{B}}$ receptor antagonist, D3R had no effect against ET-1 induced contraction (Table 3). In vascular endothelial cells, $\mathrm{ET}_{\mathrm{B}}$ receptors activation by ET and resulting $\mathrm{NO}$ release have been suggested to promote vascular relaxation and to decrease arterial blood pressure [49]. Taken into account the previous results, it is suggested that $\mathrm{D} 3 \mathrm{R}$ might stimulate $\mathrm{ET}_{\mathrm{B}}$ receptors to release $\mathrm{NO}$ that results in $\mathrm{CM}$ relaxation. The failure of iberiotoxin as $\mathrm{K}^{+}$channel inhibitor, propranolol as $\beta$-adrenoceptor antagonist and indomethacin as cyclooxygenase inhibitor to modify D3R effects on 
ET-1-induced relaxation indicates that $B$-adrenoceptors, the $\mathrm{PGI}_{2}$ pathway and $\mathrm{K}^{+}$channels were not involved in the mechanism by which D3R induced CM relaxation (Table 3).

In summary, D3R relaxed in CM stimulated with ET-1 (Figure 7). Although flavonoids (Q3R and M3R) had no activity, the C-ring structure of AC did appear to be essential for the relaxation (Figure 7). These results suggest that AC could be beneficial for prevention of myopia and glaucoma.

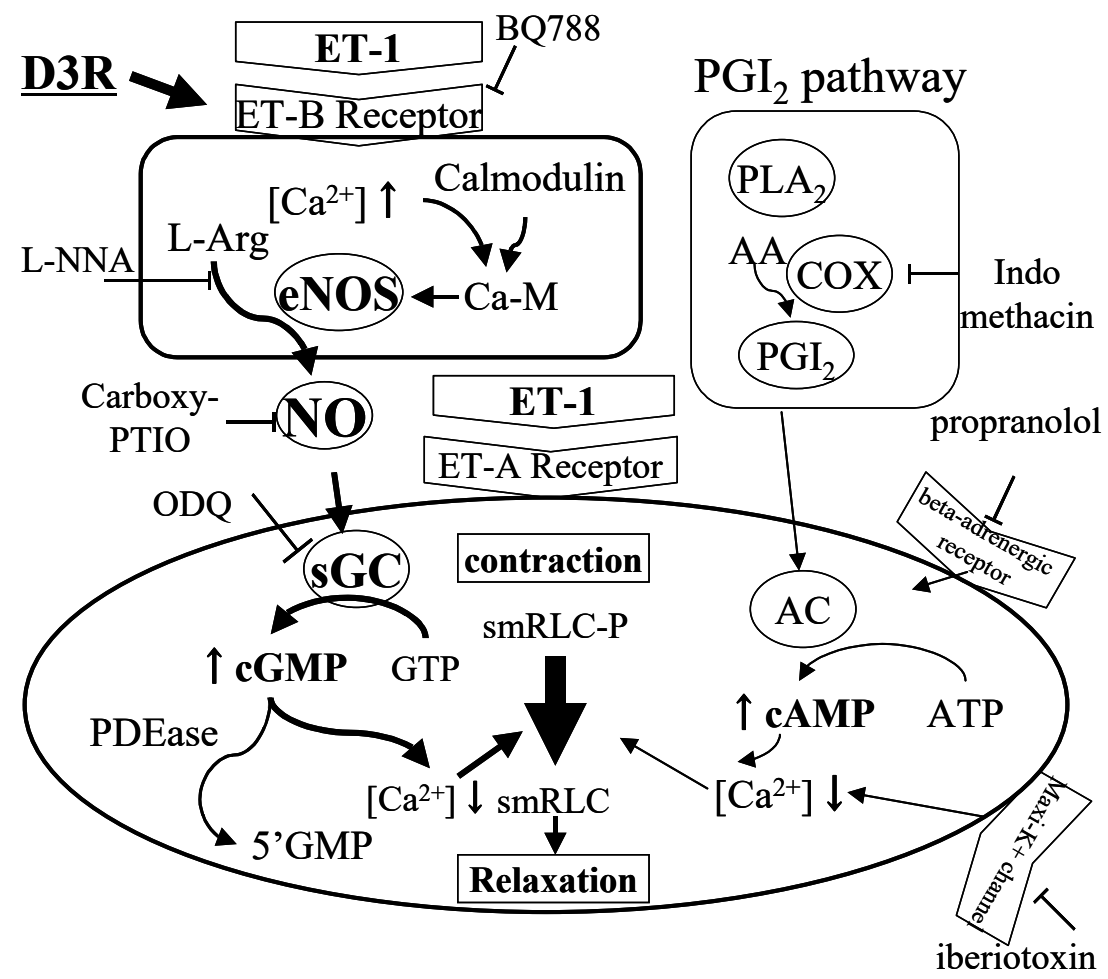

Figure 7. Schematic diagram of relaxation induced by D3R.

\section{Prevention of Myopia in a Negative Lens Fitted Chick Model}

Myopia, one of the most common ocular disorders worldwide, is a serious public health issue particularly in underdeveloped areas where resources for vision correction are not readily available. A myopia experimental model in chicks, initiated by fitting a negative lens, manifests as axial length elongation in correspondence with hyperopic defocusing and is an animal model for human myopia, particularly that which develops during school-age years [50-52]. In the myopia model on negative lens-fitted chicks, the out of focus on the retina plays an important role in axial length elongation and changes in refractive error [53].

Based on D3R-mediated inhibition of ET-1-induced CM contraction (Table 3) and C3R stimulation of rhodopsin regeneration in frog ROS membranes (Figure 2), one theory for the onset of refractive myopia is that the $\mathrm{CM}$ has a continuous spasm due to excessive contraction that occurs during close up work and compromises the spasmodic refraction of crystalline lens [10]. The effect of orally administered BCA was evaluated by a myopia model on negative lens-fitted chicks [13].

In this model, negative lenses (-8D) were attached by glue on the right eyes of 8-day-old white leghorn chicks while the left eyes acted as a control (Figure 8). 


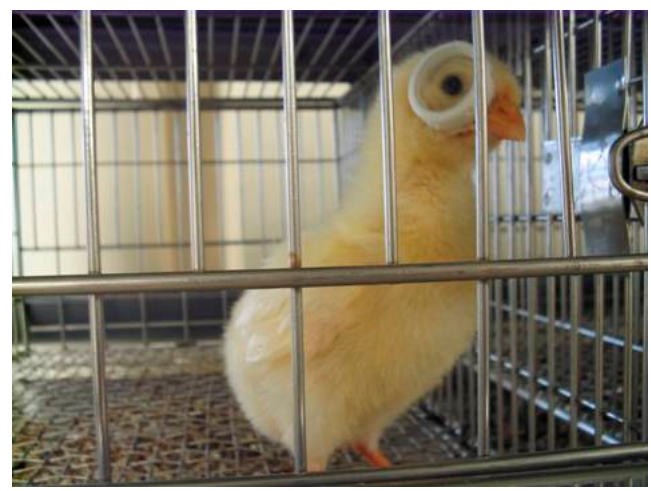

Figure 8. Photograph of a chick wearing a negative lens (-8D).

Axial length is the length in the eye ball from the anterior cornea surface to the bottom of the sclera [54]. Axial lengths of the chick eyes were measured with an A-scan ultrasound instrument [55] and elongation was calculated as:

Axial length elongation $(\mathrm{mm})=$ axial length of right eye $(\mathrm{mm})$ - axial length of left eye $(\mathrm{mm})$, Ocular length elongation $(\mathrm{mm})=$ ocular length of right eye $(\mathrm{mm})$ - ocular length of left eye $(\mathrm{mm})$.

Aqueous BCA at either $50 \mathrm{mg} / \mathrm{kg}$ BW or $100 \mathrm{mg} / \mathrm{kg}$ BW was orally administered to chicks by gavage before the application of the negative lens. Chicks then received the same BCA dose once a day for two days after fitting of a negative lens. In the control group, distilled water was administered to chicks. On the third day (72 h) after fitting of a negative lens, the axial and ocular lengths of the right eyes that had the lens increased significantly compared to those of left eyes. This result demonstrated the successful induction of myopia in chicks and was consistent with previous reports [51,52], which would allow the testing of the effects of oral BCA.

The increases in axial and ocular length caused by wearing a negative lens were significantly inhibited by orally administered BCA. The higher dose of BCA $(100 \mathrm{mg} / \mathrm{kg})$ significantly inhibited axial length elongation compared to the distilled water control $(0.22 \pm 0.033 \mathrm{~mm}$ vs. $0.41 \pm 0.042 \mathrm{~mm}$; Figure 9). A lower BCA (50 mg/kg) dose was also associated with a reduction in axial length elongation $(0.32 \pm 0.033 \mathrm{~mm})$. However, the ocular length of birds fed either the dosage of BCA was significantly shorter than that of control birds. Detailed methods and results for this study are described by Iida et al. [56].

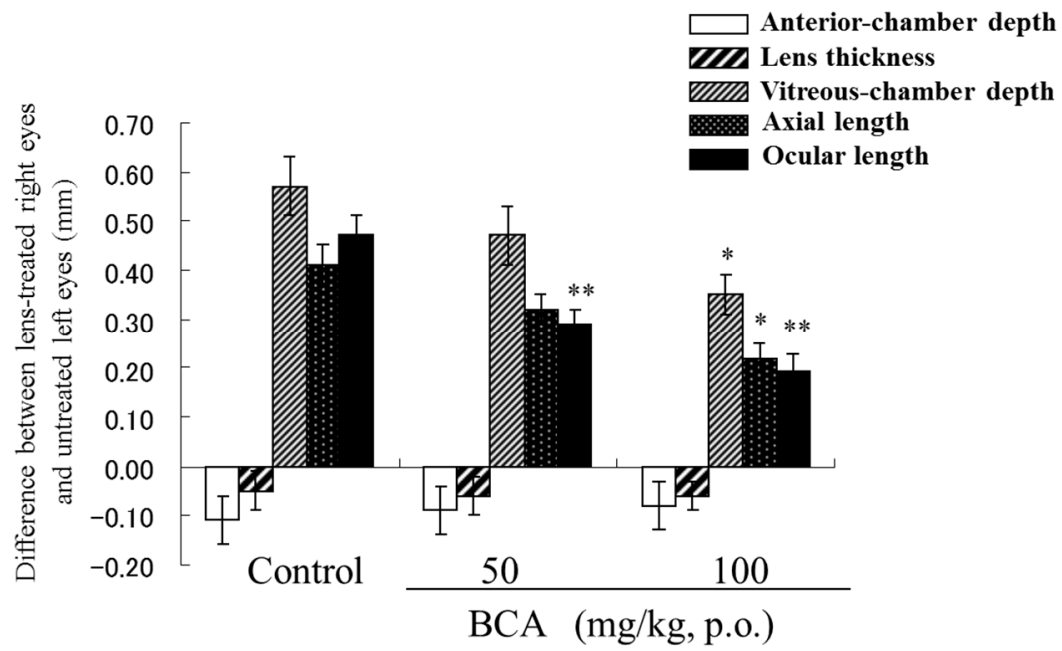

Figure 9. The blackcurrant anthocyanin (BCA) effect on enlargement of each eye component dimensions after application of a negative lens (-8D) in chicks. $n=12$, mean \pm SEM. paired $t$-test (intra-group) or Dunnett's multiple comparison test (inter-group). ${ }^{*} p<0.05$, and ${ }^{* *} p<0.01$; vs. control. 
Further studies are needed to clarify the inhibition mechanism of each AC on the elongation of axial and ocular lengths, and to provide insight into therapeutically effective doses of AC contained in BCA.

\section{Dark Adaptation Study}

AC treatment is known to improve night vision [5]. In World War II, British Air Force pilots consumed blueberry jam in night flights to obtain clear night vision [3]. In a systematic review of 30 clinical studies to examine the bilberry effect on vision in reduced light conditions, Canter and Ernst found that testing of psychophysical outcome parameters was weak evidence due to a lack of strict study designs (e.g., non-randomized or non-placebo controlled trials) [6].

Based on this review, they concluded that although bilberry AC appeared to improve normal night vision, there was a lack of evidence from rigorous clinical studies to support this effect. Therefore, we performed a clinical study of the effects of AC on dark adaptation. Healthy subjects (four males, eight females, average weight $60.5 \mathrm{~kg}$, average age 33.3 years-old) were assigned to four groups. One group was given a placebo and three groups were given different doses of BCA (50, 25 and $12.5 \mathrm{mg}$ AC/subject). This study was carried out by a double-blind, placebo-controlled, crossover study [15].

As test samples, BCA was delivered in powders packed into capsules that were the same color as that used for placebo, which contained the same amount of sucrose. Dark adaptation values were shown as the visual threshold after $30 \mathrm{~min}$ of dark adaptation compared before and $2 \mathrm{~h}$ after intake of each test drink. Each subject was tested four times with 1 week between each test. The dark adaptation threshold was measured binocularly using a Goldmann-Weekers Adaptometer after increasing the intensity of light until the subject recognized the bars and answered its correct direction. A typical profile of dark adaptation curve by one subject is shown in Figure 10.

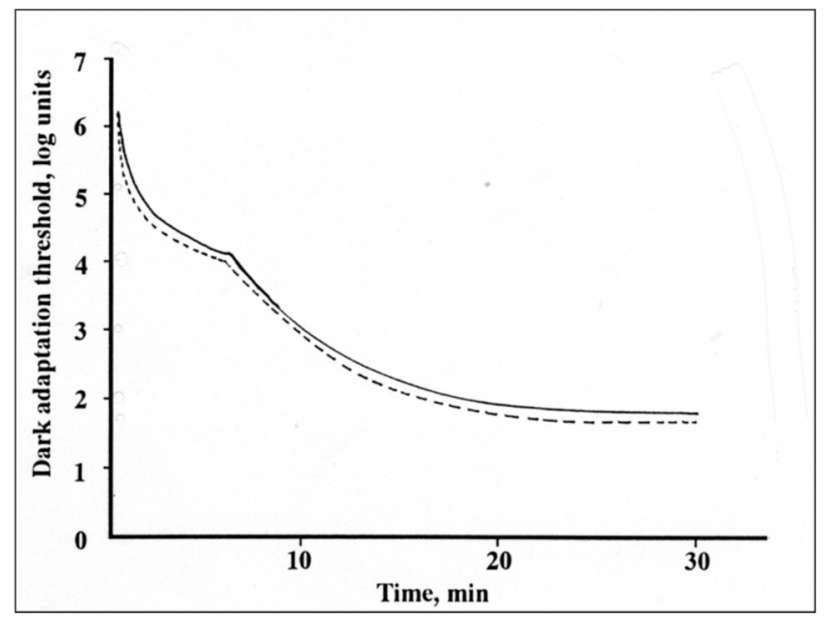

Figure 10. Typical dark adaptation curve before (continuous line) and after (dotted line) BCA intake.

Comparison of mean and standard deviations for the bottom of dark adaptation threshold by log unit (log asb) at two hours after BCA intake in the four groups were shown in Table 5. Dark adaptation value in placebo group was $2.018 \pm 0.218$. The values in AC intake groups were $2.004 \pm 0.195$ (AC, $12.5 \mathrm{mg} / \mathrm{subject}), 1.980 \pm 0.197$ (AC, $25 \mathrm{mg} /$ subject) and $1.923 \pm 0.167$ (AC, $50 \mathrm{mg} /$ subject), indicating an AC dose dependency (Table 5). At an AC dose of $50 \mathrm{mg} /$ subject, a significant difference $(p=0.014)$ was observed in threshold values after intake compared to placebo. Comparison of four AC dose groups before and after intake showed a significant difference $(p=0.011)$ for the $50 \mathrm{mg} / \mathrm{subject}$ AC dose (Table 5). 
Table 5. Dark adaptation threshold changes before and after intake of the test drink.

\begin{tabular}{ccccc}
\hline $\begin{array}{c}\text { Dose of BCA } \\
\text { mg/subject }\end{array}$ & \multicolumn{2}{c}{$\begin{array}{c}\text { Dark Adaptation Value, Mean } \pm \text { SD of Log Asb; }(\boldsymbol{p} \text { value) } \\
\text { (1) }\end{array}$} \\
\hline 0 (placebo) & $2.056 \pm 0.209(1.000)$ & $2.018 \pm 0.218(1.000)$ & $-0.038 \pm 0.106(1.000)$ & 0.244 \\
12.5 & $2.026 \pm 0.147(0.457)$ & $2.004 \pm 0.195(0.457)$ & $-0.023 \pm 0.138(0.733)$ & 0.583 \\
25 & $2.016 \pm 0.170(0.234)$ & $1.980 \pm 0.197(0.264)$ & $-0.037 \pm 0.112(0.983)$ & 0.28 \\
50 & $2.038 \pm 0.186(0.686)$ & $1.923 \pm 0.167(0.014)$ & $-0.115 \pm 0.131(0.171)$ & 0.011 \\
\hline
\end{tabular}

(1) The results of statistical analysis, independently carried out in each vertical row, are shown in parentheses.

(2) Statistical $p$ value for "after intake" vs. "before intake" in each horizontal row.

\section{Transient Refractive Alteration Study}

Accommodative alterations, or pseudo myopia following long-term near visual task, is thought to be the physiological parameter of eye fatigue [57]. The effects of BCA on transient refractive changes and asthenopia were tested in 21 healthy subjects (mean age, 20.9 years-old; range, 20-25 years). The study was a double-masked, randomized, crossover design, with subjects divided to either a BCA group or a placebo group. Each subject was tested at one-week intervals between BCA intake. The subjects were given $200 \mathrm{~mL}$ of juice containing AC (50 mg of AC/subject) or placebo. Subjects ate food $2 \mathrm{~h}$ before the visual task, and visual fatigue was compared before and after intake. The experimental near visual task was a modification of the Kraepelin test method [58]. The task using simple computer calculation was performed for $2 \mathrm{~h}$ without any rest. After completing task, the refraction values, flicker values and visual analog scale (VAS) [59] as indicators of the magnitude of asthenopia were measured.

The spherical (S) and cylindrical (C) refraction value of eye was first measured using an autorefractometer. The refraction value was evaluated in terms of the spherical equivalent of $(\mathrm{S}+\mathrm{C} / 2)$. The flicker value was next determined using critical flicker fusion (CFF) that was measured using a Flicker 501. Refraction values in dominant eye were summarized in Table 6. In the placebo trial, refraction values after the visual task showed a remarkable decrease that had borderline statistical significance (from $-0.384 \pm 0.536$ to $-0.503 \pm 0.579, p=0.064$ ). Comparison of refraction values before and after BCA intake showed that the mean values were similar. In contrast, the mean changes of BCA and placebo were $-0.030 \pm 0.252 \mathrm{D}$ and $0.119 \pm 0.278 \mathrm{D}$, respectively. This difference was statistically significant $(p=0.006)$.

Table 6. Refraction values in dominant eye, flicker values, assessment of subjective asthenopia and changes in transient refractive alteration measured before and after a visual task in subjects orally administered BCA or placebo ${ }^{1}$.

\begin{tabular}{|c|c|c|c|c|c|c|}
\hline \multirow{2}{*}{ Item \& Statement } & \multicolumn{3}{|c|}{ BCA } & \multicolumn{3}{|c|}{ Placebo } \\
\hline & Before & After ${ }^{2}$ & Change $^{2}$ & Before & After ${ }^{2}$ & Change $^{2}$ \\
\hline Refraction values & $\begin{array}{c}-0.432 \pm \\
0.602\end{array}$ & $\begin{array}{c}-0.402 \pm \\
0.643^{\mathrm{a}}\end{array}$ & $\begin{array}{l}-0.030 \pm \\
0.252^{(a), c}\end{array}$ & $\begin{array}{c}-0.384 \pm \\
0.536\end{array}$ & $\begin{array}{c}-0.503 \pm \\
0.579^{b}\end{array}$ & $\begin{array}{c}0.119 \pm 0.278 \\
\text { (b), (c) }\end{array}$ \\
\hline $\begin{array}{c}\text { Flicker value, } \mathrm{Hz} \\
\text { Asthenopia } \\
\text { symptoms (VAS mm) }\end{array}$ & $34.95 \pm 3.16$ & $34.39 \pm 3.51$ & $0.56 \pm 1.15$ & $34.72 \pm 2.99$ & $34.13 \pm 2.90$ & $0.59 \pm 1.22$ \\
\hline head \& neck & $12.70 \pm 13.45$ & $40.08 \pm 24.86$ & $27.38 \pm 18.39$ & $8.34 \pm 11.87$ & $44.09 \pm 26.09$ & $35.75 \pm 24.96$ \\
\hline arm & $10.21 \pm 17.82$ & $36.15 \pm 25.86$ & $25.94 \pm 29.61$ & $4.32 \pm 6.27$ & $41.76 \pm 29.33$ & $37.44 \pm 28.43$ \\
\hline eye & $14.72 \pm 15.55$ & $47.31 \pm 24.72$ & $\begin{array}{c}32.59 \pm 18.94 \\
\text { (a) }\end{array}$ & $14.59 \pm 17.98$ & $56.72 \pm 25.24$ & $\underset{\text { (b) }}{42.14 \pm} 19.52$ \\
\hline shoulder & $15.12 \pm 15.65$ & $49.66 \pm 27.97$ & $34.54 \pm 25.75$ & $10.95 \pm 17.42$ & $54.31 \pm 29.31$ & $43.36 \pm 30.91$ \\
\hline low back & $10.63 \pm 15.92$ & $29.79 \pm \frac{27.15}{a}$ & $19.16 \pm \underset{\text { (a) }}{22.74}$ & $7.35 \pm 9.25$ & $42.83 \pm \frac{\mathrm{b}}{\mathrm{b}} 33.55$ & $35.48 \pm 30.87$ \\
\hline
\end{tabular}

${ }^{1}$ Expressed as mean \pm SD. ${ }^{2}$ Statistical analysis comparing the values after the test and the change in values was independently carried out in each horizontal row. a, b, c, (a), (b), (c) Values with different superscript letters are significantly different $(p<0.05)$. 
Flicker values did not show differences between BCA and placebo groups (Table 6). Mean values for the five criteria used as subjective assessment of asthenopia were higher in every group after the task, but the increase was smaller for the BCA group. Furthermore, there was a significant difference in values for BCA and placebo for asthenopia symptoms at two sites, the eye and the lower back.

Another name for transient myopic shifts is pseudo myopia, which is common in young people, but now occurs frequently among elderly people as well [60]. Patients with ophthalmologic disease often consume AC and have improvement in subjective disease symptoms. Thus, the rate of AC consumption for conditions such as pseudo myopia has increased, although AC is not effective for mitigation of symptoms for all ophthalmologic disorders.

\section{Clinical Study of AC Effects in Glaucoma Patients}

Glaucoma is an intractable disease and the major reason of blindness in worldwide [61]. The increasing intraocular pressure (IOP) is the predominant factors for onset of glaucoma, although lowering elevated IOP by medication or surgical intervention is often insufficient to prevent glaucoma progression [62]. As D3R potentially activates $\mathrm{ET}_{\mathrm{B}}$ receptors to promote $\mathrm{NO}$ release [9], we hypothesized that AC may alter ET-1 receptor-mediated ET-1 metabolism to impact the hemodynamics of retinal blood circulation and in turn alter blood flow at optic nerve heads.

In a clinical study, thirty consecutive hospital visit patients (age range, 51-80; mean age $66.7 \pm 6.9$ years-old, nine males and 21 females) with normal tension glaucoma (NTG) received $50 \mathrm{mg}$ orally administered BCA once daily for 6 months [63]. Blood flow at the neuroretinal rim of the optic nerve head and peripapillary retina was evaluated using a scanning laser Doppler flow meter both before and after 6 months of administration [64]. The IOP for every patient almost remained stable in BCA group during the test period. However, ET-1 concentrations in plasma had significantly increased from $3.27 \pm 1.67$ (mean \pm S.D.) $\mathrm{pg} / \mathrm{mL}$ to $4.10 \pm 2.14 \mathrm{pg} / \mathrm{mL}$ before and just after the administration period, respectively $(p<0.05)$. After administration, the blood flow of the superior (Sup) and inferior (Inf) temporal neuroretinal rim of the optic nerve head and peripapillary retina in both eyes were significantly altered (Table 7).

Table 7. Retinal blood flow of the superior temporal rim/retina and inferior temporal/retina after consumption of anthocyanins for 6 months in the left eye (LE) and right eye (RE).

\begin{tabular}{ccc}
\hline Treatment & $\begin{array}{c}\text { Before } \\
\text { (Average } \pm \text { SE) }\end{array}$ & $\begin{array}{c}\text { After 6 Month } \\
\text { (Average } \pm \text { SE) }\end{array}$ \\
\hline Sup. temp. rim (RE) & $507.7 \pm 174.3$ & $638.6^{\mathrm{a}} \pm 191.2$ \\
Inf. temp. rim (RE) & $393.6 \pm 138.0$ & $582.2^{\mathrm{b}} \pm 177.8$ \\
Sup. temp. retina (RE) & $457.6 \pm 140.6$ & $595.1^{\mathrm{b}} \pm 171.5$ \\
Inf. Temp. retina (RE) & $377.0 \pm 80.5$ & $519.1^{\mathrm{b}} \pm 130.0$ \\
Sup. temp. rim (LE) & $442.4 \pm 214.3$ & $662.4^{\mathrm{b}} \pm 185.3$ \\
Inf. temp. rim (LE) & $466.5 \pm 216.3$ & $653.7^{\mathrm{b}} \pm 260.9$ \\
Sup. temp. retina (LE) & $375.0 \pm 75.9$ & $442.2^{\mathrm{b}} \pm 80.1$ \\
inf. temp. rim (LE) & $444.9 \pm 100.9$ & $546.9^{\mathrm{a}} \pm 185.8$ \\
\hline
\end{tabular}

Neuroretinal rim and peripapillary retinal blood flow, which are correlated with degradation of visual field $[65,66]$, were both significantly reduced in patients with NTG compared to healthy individuals.

Ohguro et al. also conducted a randomized, placebo-controlled, double-masked 24-month study on the effects of BCA treatment on progression in 38 open-angle glaucoma (OAG) patients treated with anti-glaucoma drops [16]. They found that BCA treatment $(50 \mathrm{mg} /$ day, $n=19)$ reduced the degradation of the visual field and elevations in retinal blood flow of OAG. The BCA group had significantly better ocular blood circulation relative to both baseline values and placebo-treated patients as measured by 
the Humphrey visual field mean deviation in the eye $(p=0.039)$. However, other systemic and ocular conditions showed no significant changes in both groups.

In another study of OAG patients, Ohguro et al. found that the concentration of serum ET-1 among OAG patients was significantly lower than that in healthy subjects $(p<0.05)$. After BCA intake, ET-1 concentration in serum increased to levels that were similar to those of healthy subjects, whereas ET-1 values for placebo-treated patients remained lower [17]. The results of these clinical studies suggest that AC intake might be a low risk and effective option for neuroprotective treatment with OAG and NTG patients.

\section{Conclusions}

Antioxidative flavonoids such as AC are abundant in fruits and vegetables. The therapeutic application of AC by the ophthalmological field has shown potential for improving eye health. In this review, we summarized several studies showing that $\mathrm{AC}$ has specific effects on rhodopsin regeneration and smooth muscle relaxation in vitro. In studies in vivo, AC was present in eye tissues and improved blood circulation. These findings were also reflected in clinical trials of BCA to improve vision health and together these studies suggest that BCA could be an effective nutraceutical product for the treatment and prevention of an optical disorder.

However, the use of AC in the pharmaceutical field is limited by its low bioavailability and instability at neutral $\mathrm{pH}$. Moreover, AC degradation products were difficult to be tracted and evaluated in in vitro studies. Further studies are needed to determine the structure of AC degradation products at neutral $\mathrm{pH}$ and confirm its functionality at physiological conditions.

Author Contributions: Y.N.-writing, editing; K.I.-K.-writing, editing; H.M.-writing, editing, reviewing, supervising experiments.

Funding: This work was supported by JSPS KAKENHI Grant-in-Aid for Scientific Research(C)18K11113.

Conflicts of Interest: The authors declare no conflict of interest.

\section{References}

1. Tyrrell, R.A.; Leibowitz, H.W. The relation of vergence effort to reports of visual fatigue following prolonged near work. Hum. Factors 1990, 32, 341-357. [CrossRef] [PubMed]

2. Murata, K.; Araki, S.; Yokoyama, K.; Yamashita, K.; Okumatsu, T.; Sakou, S. Accumulation of VDT work-related visual fatigue assessed by visual evoked potential, near point distance and critical flicker fusion. Ind. Health 1996, 34, 61-69. [CrossRef] [PubMed]

3. Morazzoni, P.; Bombardelli, E. Vaccinim myrtillus L. Fitoterapia 1996, 67, 3-29.

4. Tsuda, T.; Osawa, T. Anthocyanin. J. Eye 2008, 25, 1393-1395.

5. Jayle, G.E.; Aubert, L. Action of anthocyanin glycosides on the scopic and mesopic vision of the normal subject. Therapie 1964, 19, 171-185. [PubMed]

6. Canter, P.H.; Ernst, E. Anthocyanosides of Vaccinium myrtillus (bilberry) for night vision-A systematic review of placebo-controlled trials. Surv. Ophthalmol. 2004, 49, 38-50. [CrossRef] [PubMed]

7. Kalt, W.; Hanneken, A.; Milbury, P.; Tremblay, F. Recent research on polyphenolics in vision and eye health. J. Agric. Food Chem. 2010, 58, 4001-4007. [CrossRef] [PubMed]

8. Matsumoto, H.; Hanamura, S.; Kawakami, T.; Sato, Y.; Hirayama, M. Preparative-scale isolation of four anthocyanin components of black currant (Ribes nigrum L.) fruits. J. Agric. Food Chem. 2001, 49, 1541-1545. [CrossRef] [PubMed]

9. Matsumoto, H.; Kamm, K.E.; Stull, J.T.; Azuma, H. Delphinidin-3-rutinoside relaxes the bovine ciliary smooth muscle through activation of ETB receptor and NO/cGMP pathway. Exp. Eye Res. 2005, 80, 313-322. [CrossRef]

10. Tokoro, T. Developmental mechanism of low myopia and therapeutic possibilities. A review. Nippon Ganka Gakkai Zasshi 1998, 102, 796-812. [PubMed] 
11. Beauregard, C.; Liu, Q.; Chiou, G.C. Effects of nitric oxide donors and nitric oxide synthase substrates on ciliary muscle contracted by carbachol and endothelin for possible use in myopia prevention. J. Ocul. Pharmacol. Ther. 2001, 17, 1-9. [CrossRef] [PubMed]

12. Matsumoto, H.; Nakamura, Y.; Tachibanaki, S.; Kawamura, S.; Hirayama, M. Stimulatory effect of cyanidin 3-glycosides on the regeneration of rhodopsin. J. Agric. Food Chem. 2003, 51, 3560-3563. [CrossRef] [PubMed]

13. Iida, H.; Nakamura, Y.; Matsumoto, H.; Takeuchi, Y.; Harano, S.; Ishihara, M.; Katsumi, O. Effect of black-currant extract on negative lens-induced ocular growth in chicks. Ophthalmic Res. 2010, 44, 242-250. [CrossRef] [PubMed]

14. Iida, H.; Nakamura, Y.; Matsumoto, H.; Kawahata, K.; Koga, J.; Katsumi, O. Differential effects of black currant anthocyanins on diffuser-or negative lens-induced ocular elongation in chicks. J. Ocul. Pharmacol. Ther. 2013, 29, 604-609. [CrossRef] [PubMed]

15. Nakaishi, H.; Matsumoto, H.; Tominaga, S.; Hirayama, M. Effects of black currant anthocyanoside intake on dark adaptation and VDT work-induced transient refractive alteration in healthy humans. Altern. Med. Rev. 2000, 5, 553-562. [PubMed]

16. Ohguro, H.; Ohguro, I.; Katai, M.; Tanaka, S. Two-year randomized, placebo-controlled study of black currant anthocyanins on visual field in glaucoma. Ophthalmologica 2012, 228, 26-35. [CrossRef] [PubMed]

17. Yoshida, K.; Ohguro, I.; Ohguro, H. Black currant anthocyanins normalized abnormal levels of serum concentrations of endothelin-1 in patients with glaucoma. J. Ocul. Pharmacol. Ther. 2013, 29, 480-487. [CrossRef] [PubMed]

18. Kuntz, S.; Rudloff, S.; Asseburg, H.; Borsch, C.; Frohling, B.; Unger, F.; Dold, S.; Spengler, B.; Rompp, A.; Kunz, C. Uptake and bioavailability of anthocyanins and phenolic acids from grape/blueberry juice and smoothie in vitro and in vivo. Br. J. Nutr. 2015, 113, 1044-1055. [CrossRef] [PubMed]

19. Mueller, D.; Jung, K.; Winter, M.; Rogoll, D.; Melcher, R.; Richling, E. Human intervention study to investigate the intestinal accessibility and bioavailability of anthocyanins from bilberries. Food Chem. 2017, 231, $275-286$. [CrossRef] [PubMed]

20. Rohrig, T.; Kirsch, V.; Schipp, D.; Galan, J.; Richling, E. Absorption of anthocyanin rutinosides after consumption of a blackcurrant (Ribes nigrum L.) Extract. J. Agric. Food Chem. 2019, 67, 6792-6797. [CrossRef] [PubMed]

21. Matsumoto, H.; Inaba, H.; Kishi, M.; Tominaga, S.; Hirayama, M.; Tsuda, T. Orally administered delphinidin 3-rutinoside and cyanidin 3-rutinoside are directly absorbed in rats and humans and appear in the blood as the intact forms. J. Agric. Food Chem. 2001, 49, 1546-1551. [CrossRef] [PubMed]

22. Borges, G.; Roowi, S.; Rouanet, J.M.; Duthie, G.G.; Lean, M.E.; Crozier, A. The bioavailability of raspberry anthocyanins and ellagitannins in rats. Mol. Nutr. Food Res. 2007, 51, 714-725. [CrossRef] [PubMed]

23. Vitaglione, P.; Donnarumma, G.; Napolitano, A.; Galvano, F.; Gallo, A.; Scalfi, L.; Fogliano, V. Protocatechuic acid is the major human metabolite of cyanidin-glucosides. J. Nutr. 2007, 137, 2043-2048. [CrossRef] [PubMed]

24. Czank, C.; Cassidy, A.; Zhang, Q.; Morrison, D.J.; Preston, T.; Kroon, P.A.; Botting, N.P.; Kay, C.D. Human metabolism and elimination of the anthocyanin, cyanidin-3-glucoside: A (13)C-tracer study. Am. J. Clin. Nutr. 2013, 97, 995-1003. [CrossRef] [PubMed]

25. Matsumoto, H.; Nakamura, Y.; Iida, H.; Ito, K.; Ohguro, H. Comparative assessment of distribution of blackcurrant anthocyanins in rabbit and rat ocular tissues. Exp. Eye Res. 2006, 83, 348-356. [CrossRef] [PubMed]

26. Ansari, J.A.; Naz, S.; Tarar, O.M.; Siddiqi, R.; Haider, M.S.; Jamil, K. Binding effect of proline-rich-proteins (PRPs) on in vitro antimicrobial activity of the flavonoids. Braz. J. Microbiol. 2015, 46, 183-188. [CrossRef] [PubMed]

27. Burns, M.E.; Baylor, D.A. Activation, deactivation, and adaptation in vertebrate photoreceptor cells. Annu. Rev. Neurosci. 2001, 24, 779-805. [CrossRef] [PubMed]

28. Emeis, D.; Kuhn, H.; Reichert, J.; Hofmann, K.P. Complex formation between metarhodopsin II and GTP-binding protein in bovine photoreceptor membranes leads to a shift of the photoproduct equilibrium. FEBS Lett. 1982, 143, 29-34. [CrossRef]

29. Tachibanaki, S.; Imai, H.; Mizukami, T.; Okada, T.; Imamoto, Y.; Matsuda, T.; Fukada, Y.; Terakita, A.; Shichida, Y. Presence of two rhodopsin intermediates responsible for transducin activation. Biochemistry 1997, 36, 14173-14180. [CrossRef] 
30. Virmaux, N.; Bizec, J.C.; Nullans, G.; Ehret, S.; Mandel, P. Modulation of rod cyclic GMP-phosphodiesterase activity by anthocyanidin derivatives. Biochem. Soc. Trans. 1990, 18, 686-687. [CrossRef]

31. Bastide, P.; Rouher, F.; Tronche, P. Rhodopsin and anthocyanosides. Apropos of various experimental facts. Bull. Des Soc. D'ophtalmologie De Fr..

32. Fain, G.L.; Matthews, H.R.; Cornwall, M.C.; Koutalos, Y. Adaptation in vertebrate photoreceptors. Physiol. Rev. 2001, 81, 117-151. [CrossRef] [PubMed]

33. Thieme, H.; Stumpff, F.; Ottlecz, A.; Percicot, C.L.; Lambrou, G.N.; Wiederholt, M. Mechanisms of action of unoprostone on trabecular meshwork contractility. Investig. Ophthalmol. Vis. Sci. 2001, 42, 3193-3201.

34. Prasanna, G.; Dibas, A.I.; Yorio, T. Cholinergic and adrenergic modulation of the $\mathrm{Ca}^{2+}$ response to endothelin-1 in human ciliary muscle cells. Investig. Ophthalmol. Vis. Sci. 2000, 41, 1142-1148.

35. Kamikawatoko, S.; Tokoro, T.; Azuma, H.; Hamasaki, H.; Ishida, A. The effects of endothelin-1 on isolated bovine ciliary muscles. Exp. Eye Res. 1995, 61, 559-564. [CrossRef]

36. Azuma, H.; Masuda, H.; Sato, J.; Niwa, K.; Tokoro, T. A possible role of endogenous inhibitor for nitric oxide synthesis in the bovine ciliary muscle. Exp. Eye Res. 1997, 64, 823-830. [CrossRef]

37. Goh, Y.; Hotehama, Y.; Mishima, H.K. Characterization of ciliary muscle relaxation induced by various agents in cats. Investig. Ophthalmol. Vis. Sci. 1995, 36, 1188-1192.

38. Seeram, N.P.; Momin, R.A.; Nair, M.G.; Bourquin, L.D. Cyclooxygenase inhibitory and antioxidant cyanidin glycosides in cherries and berries. Phytomed. Int. J. Phytother. Phytopharm. 2001, 8, 362-369. [CrossRef]

39. Berridge, M.J. Smooth muscle cell calcium activation mechanisms. J. Physiol. 2008, 586, 5047-5061. [CrossRef]

40. Allen, B.G.; Walsh, M.P. The biochemical basis of the regulation of smooth-muscle contraction. Trends Biochem. Sci. 1994, 19, 362-368. [CrossRef]

41. Walsh, M.P. The Ayerst Award Lecture 1990. Calcium-dependent mechanisms of regulation of smooth muscle contraction. Biochem. Cell Biol. 1991, 69, 771-800. [CrossRef]

42. Ikebe, M.; Hartshorne, D.J. Phosphorylation of smooth muscle myosin at two distinct sites by myosin light chain kinase. J. Biol. Chem. 1985, 260, 10027-10031.

43. Ikebe, M.; Hartshorne, D.J.; Elzinga, M. Identification, phosphorylation, and dephosphorylation of a second site for myosin light chain kinase on the 20,000-dalton light chain of smooth muscle myosin. J. Biol. Chem. 1986, 261, 36-39.

44. Hartshorne, D.J.; Ito, M.; Erdodi, F. Role of protein phosphatase type 1 in contractile functions: Myosin phosphatase. J. Biol. Chem. 2004, 279, 37211-37214. [CrossRef]

45. Lau, K.S.; Grange, R.W.; Chang, W.J.; Kamm, K.E.; Sarelius, I.; Stull, J.T. Skeletal muscle contractions stimulate cGMP formation and attenuate vascular smooth muscle myosin phosphorylation via nitric oxide. FEBS Lett. 1998, 431, 71-74. [CrossRef]

46. Nathanson, J.A.; McKee, M. Identification of an extensive system of nitric oxide-producing cells in the ciliary muscle and outflow pathway of the human eye. Investig. Ophthalmol. Vis. Sci. 1995, 36, 1765-1773.

47. Masuda, H.; Tamaoki, S.; Goto, M.; Ishida, A.; Kamikawatoko, S.; Tokoro, T.; Azuma, H. Nitric oxide-induced ciliary muscle relaxation during contraction with endothelin-1 is mediated through elevation of cyclic GMP. Curr. Eye Res. 1997, 16, 1245-1251. [CrossRef]

48. Kamikawatoko, S.; Tokoro, T.; Ishida, A.; Masuda, H.; Hamasaki, H.; Sato, J.; Azuma, H. Nitric oxide relaxes bovine ciliary muscle contracted by carbachol through elevation of cyclic GMP. Exp. Eye Res. 1998, 66, 1-7. [CrossRef]

49. Russell, F.D.; Skepper, J.N.; Davenport, A.P. Detection of endothelin receptors in human coronary artery vascular smooth muscle cells but not endothelial cells by using electron microscope autoradiography. J. Cardiovasc. Pharmacol. 1997, 29, 820-826. [CrossRef]

50. Mutti, D.O.; Zadnik, K.; Adams, A.J. Myopia. The nature versus nurture debate goes on. Investig. Ophthalmol. Vis. Sci. 1996, 37, 952-957.

51. Schaeffel, F.; Glasser, A.; Howland, H.C. Accommodation, refractive error and eye growth in chickens. Vis. Res. 1988, 28, 639-657. [CrossRef]

52. Wildsoet, C.; Wallman, J. Choroidal and scleral mechanisms of compensation for spectacle lenses in chicks. Vis. Res. 1995, 35, 1175-1194. [CrossRef]

53. Wildsoet, C. Neural pathways subserving negative lens-induced emmetropization in chicks-insights from selective lesions of the optic nerve and ciliary nerve. Curr. Eye Res. 2003, 27, 371-385. [CrossRef] 
54. McFadden, S.A.; Howlett, M.H.; Mertz, J.R.; Wallman, J. Acute effects of dietary retinoic acid on ocular components in the growing chick. Exp. Eye Res. 2006, 83, 949-961. [CrossRef]

55. Rohrer, B.; Spira, A.W.; Stell, W.K. Apomorphine blocks form-deprivation myopia in chickens by a dopamine D2-receptor mechanism acting in retina or pigmented epithelium. Vis. Neurosci. 1993, 10, 447-453. [CrossRef]

56. Iida, H.; Nakamura, Y.; Matsumoto, H.; Kawahata, K.; Koga, J.; Katsumi, O. Effect of black currant anthocyanins on elongation of ocular components in chick myopia models: Specific structures of anthocyanins are essential for inhibitory effect of ocular elongation. Investig. Ophthalmol. Vis. Sci. 2011, 52, 6297.

57. Grandjean, E.; Vigliani, E. Ergonomic Aspect of VDTs; Taylor and Francis Co.: London, UK, 1980.

58. Institute, J.P. Uchida-Kraepelin Psychological Test Data Book; Kaneko-shobo: Tokyo, Japan, 1990; pp. $104-121$.

59. Kirshner, B.; Guyatt, G. A methodological framework for assessing health indices. J. Chronic Dis. 1985, 38, 27-36. [CrossRef]

60. Yamaguchi, K.; Horibe, M.; Uozato, H.; Shimizu, K. Change in axial length and anterior chamber depth according to near work. Jpn. Orthopt. J. 2005, 34, 115-119. [CrossRef]

61. Shields, M.B.; Shields, M.B. Textbook of Glaucoma; Williams \& Wilkins Baltimore: Baltimore, MD, USA, 1992.

62. Anderson, D.R.; Drance, S.M.; Schulzer, M. Natural history of normal-tension glaucoma. Ophthalmology 2001, 108, 247-253. [CrossRef]

63. Ohguro, I.; Ohguro, H.; Nakazawa, M. Effects of anthocyanins in black currant on retinal blood flow circulation of patients with normal tension glaucoma. A pilot study. Hirosaki Med. J. 2007, 59, $23-32$.

64. Sato, E.A.; Ohtake, Y.; Shinoda, K.; Mashima, Y.; Kimura, I. Decreased blood flow at neuroretinal rim of optic nerve head corresponds with visual field deficit in eyes with normal tension glaucoma. Graefe's Arch. Clin. Exp. Ophthalmol. 2006, 244, 795-801. [CrossRef]

65. Logan, J.F.; Rankin, S.J.; Jackson, A.J. Retinal blood flow measurements and neuroretinal rim damage in glaucoma. Br. J. Ophthalmol. 2004, 88, 1049-1054. [CrossRef]

66. Yaoeda, K.; Shirakashi, M.; Fukushima, A.; Funaki, S.; Funaki, H.; Abe, H.; Tanabe, N. Relationship between optic nerve head microcirculation and visual field loss in glaucoma. Acta Ophthalmol. Scand. 2003, 81, 253-259. [CrossRef]

(C) 2019 by the authors. Licensee MDPI, Basel, Switzerland. This article is an open access article distributed under the terms and conditions of the Creative Commons Attribution (CC BY) license (http://creativecommons.org/licenses/by/4.0/). 